new combinations of social and commercial of it has been cultivated with a zeal and relation; and giving to the fickleness of energy which have assuredly met their full winds, and the faithlessness of waves, the cer. tainty and steadiness of a highway upon the and ?"

An important feature in Mr. Hoblyn's manual, and one calculated to be of great benefit to the student, is the introduction at the end of each chapter of a series of questions upon the principal points discussed in each division. The plan of the work is thus briefly stated by the author:-

"The plan which will be adopted in this treatise will comprise three sections. The first section will be devoted to the consideration of the Imponderable Agents of Chemistry. The second section will be devoted to the Chemistry of Inorganic Bodies. This section will embrace the laws of chemical affinity and combination, together with the chemical history of all the elementary bodies, and of the compounds which belong to inorganic matter. Of the elementary bodies, oxygen performs a most prominent part in the operations of $\mathrm{Na}$ ture, from its tendency to combine with other bodies, and from the importance of the compounds it forms with them; this element will, therefore, be considered first. For the same reasons, in considering the other elementary bodies, the combination of each of them with oxygen will be particularly noticed. The other compounds which the non-metallic substances form with each other will next be considered. The metallic substances will be treated of, each in its individual character, and with reference to its combinations with the non-metallic substances and with each other. The third section will be devoted to the Chemistry of Organic Bodies, which may be divided into the products of vegetable and those of animal life."

With another short extract, in which the author pourtrays vividly the objects of his labours, and the essential advantages of the science, we shall conclude; which we do with the fervent hope that so valuable a science as chemistry will not be neglected by the medical student, to whom we again recommend the perusal of the little volume before us.

"The object of this treatise is to make the student acquainted with the facts which chemistry is daily presenting to our notice, to enable him, from consideration of these facts, to contemplate the laws which regulate the economy of Nature, to stimulate him to pursue the science even into its farthest recesses. Let him not suppose that all has been effected. ' 'Science,' observes Sir J. Herschel, ' in re. lation to our faculties, still remains boundless and unexplored; and, after the lapse of a century and a half from the era of Newton's discoveries, during which every department return, we remain in the situation in which he figured himself-standing on the shore of a wide ocean, from whose beach rve may bave culled some of those innumerable beautiful productions it casts up with lavish prodigality, but whose acquisition can be regarded as no diminution of the treasures that remain."

\title{
BIOGRAPHICAL NOTICE
}

OF THE LATE

THOMAS HODSON, ESQ., Surgeon, of Lewes.

By Gideon Mantell, LL.D., F.R.S.

THE death of an eminent physician or sur. geon is not only a loss to the domestic circle, and to the inhabitants of the neighborrhood in which his talents were exerted, but also to the community at large; for with such a man perishes a vast store of kuow. ledge and experience, which cannot be com. muaicated to others, or be bequeathed to those who shall come after. This remark applies even to individuals who have largely contributed to the professional literature of their time; but it bears with still greater force on one who, engaged in extensive practice, is unable or unwilling to record bis opinions and ex perience. The great loss which surgical science and suffering huma. nity have sustained by the death of Sir Astley Cooper will not be questioned; yet, in the metropolis, that grand mart for talent and ability of every kind, the crowd of able surgeons ready to supply the place of de. parted excellence, renders the bereavement less obvious and important. But in a provincial district, the removal by death of a professional man who, gifted with great natural abilities, had enjoyed the advantages of a sound medico-chirurgical education, had been engaged in practice for more than half a century, and during that long period had maintained an intercourse with the prin. cipal surgeons and physicians of the metropolis, and had kept pace with the advanee. ment of professional knowledge, is a loss to society which caunot readily be supplied. Such a loss the county of Sussex has sus. tained by the death of that eminent surgeon, T. Hodson, Esq., of Lewes. This gentleman was the son of the late Rev. J. Hod. son, of OId-place, Sandhurst, Kent, and was born at the residence of his father in 1762 . After the usual course of scholastic edncation, and a surgical apprenticeship of five years, Mr. Hodson became a student at the Borough Hospitals, and was a pupil of Mr. Cline, at the same time as the late Sir A. Cooper, with whom he contracted an in. timacy that ripened into a friendship, which terminated but with life. Having com. 
pleted his studies at the hospitals, he was admitted a nember of the College of Surgeons, and shortly after established himself in Lewes as a general practitioner, about the year 1787. Mr. Hodson's early career differed in no respect from the common lot of those who commence practice in a country town-labouring hard for a scanty pittance, and considering himself fortunate if the receipts of practice covered an expenditure conducted with the most rigid economy. At this period the vile system of letting out the professional attendance on the parochial poor, by tender, was introduced; and to the honour of Mr. Hodson it must be recorded, that he constantly refused to be a party to a measure alike degrading to the medical pro. fession, and unjust towards the unfortunate paupers, who were frequently consigned to the inexperience and ignorance of the young practitioner that happened to be the lowe-t bidder, and this, too, for a paltry saving of five or ten pounds a-year in the surgeon's salary; while it frequently happened that ten times that sum was expended in the after-support of the patients whose illness or injuries were protracted or rendered incurable by the inattention or inexperience of the cheapest doctor. After several years spent in the assiduous discharge of the duties of a practice, very limited, and of a character by no means commensurate with his deserts, Mr. Hodson began to think seriously of a removal from Lewes, intending to establish himself either in London or Brighton, which was then rapidly rising in importance. Circumstances, however, occurred to make him abandon this intention; but which, notwithstanding his brilliant career in I.ewes, he ever deeply regretted. At this time Dr. Bayford, who had been an eminent practitioner in London, and had retired from practice in consequence of a delicate state of health, took up his residence in Lewes, and soon found himself consulted by the principal families in the neighbourhood. Desirous of avoiding the fatigues of practice thus unsolicitedly pressed upon him, and finding in Mr. Hodson a young man of decided ability and of great promise, Dr. Bayford strongly reconmended him to his patjents. It was, too, at this gentleman's suggestion that Mr. Hodson was induced to undertake the operation of lithotomy; and the first case on which be operated proving eminently successful, he obtained the reputation of a skilful operating surgeon, which subsequent practice fully established. Persons afficted with calculus came from all parts of the county to consult him, and for a long course of years he operated without one fatal result; and although at length a few cases temiuated unfrourably, yet upon the whole his success as a lithotonist stands very high, and has seldom been surpassed. When seventy years of age, this veteran surgeun operated successfully, and removed a stone weighing six and a quarter ounces, from a patient at Winchelsea. Nor was Mr. Hodson less skilful in other departments of surgery ; indeed, for a long period he was the leading surgeon of that part of England, and was consulted in most cases of importance by his professional brethren. As a physician and accoucheur he was equally eminent; prompt, decisive, energetic, yet cautious in practice; kind and affable in manuer and deportment; unremitting in attention, and deeply interested in the welfare of his patients; generous and liberal in the extreme; he was beloved and respected by all classes.

The writer of this imperfect sketch has often attended with him in cases of difficulty and danger, and assisted him in numerous important operations (lithotomy, amputation, hernia, aneurism, \&c.); and allhough it has since been his lot to attend in consultation with many of the leading surgeons of the metropolis, he can declare that he has never seen surpassed the skill, presence of mind, and humane and indefatigable attentiun of the late Mr. Hodson. The desire of advancing medical science was in the subject of this memoir a passion which prevailed to the last moments of his existence. At a time when violent prejud ices prevailed against anatomical inspections, he spared no pains to remove those erroneous impressions, and nerer neglected a post-mortem examination when permitted, however much he might be fatigued and harassed by engagements. On one occasion he accidentally wounded the finger of the writer who was assisting him in the examination of a body, and nothing could exceed Mr. Hodson's kind anxiety lest the accident shonld be attended with serious consequences, as it at first threatened to be. On the day before the paralytic seizure which terminated Mr. Hodson's valuable existence, he performed the postmortem examination of the body of an old friend, who had left a written request to that effect. Mr. Hodson, like his friend Sir A. Cooper, therefore, died "in harness," as the latter used to express a wish to do ; for he continued the exercise of $h$ is profession in his seventy-ninth year, until three days before his decease. Unremittingly engaged in practice, and devoting his few leisure hours to the sports of the field, or to cricket (an amusement to which he was much altached), Mr. Hodson has, we fear, left but few notes of his practice and experience. Had he removed to London, as he contemplated some twenty years since, there can be no doubt that he would hare taken a foremost place among the surgeons of the metropolis; and his name would have bee associated with that of Cooper, Cline, Abernethy, and other eminent men who have shed a lustre upon British surgery. But if the sphere of his exertions was less lofty, it was not less useful and important, and it involved far more 
arduous duties: Mr. Hodson's was, indeed, a life of labour, for which the pecuniary reward was very inadequate. In no other profession would such talents and exertions have been productive of so little benefit to the individual ; the proceeds of his practice, we believe, never much exceeded $2000 l$. per annum, for an amount of medical and surgical skill and labonr, which in the metropolis would have realised five or six times that sum. Mr. Hodson has left no son; but he has a nephew in the profession, and it is to be hoped that this gentleman will endeavour to preserve some record of his uncle's professional opinions and experience, and do justice to his memory, by a far more elaborate and faithful sketch of his life and character, than the scanty materials in the possession of the writer of this brief notice have enabled him to attempt.

In this feeble tribute to the excellence and professional endowments of a practi. tioner with whom, for more than a quarter of a century, he was placed in the position of a rival, and in daily professional competition, the writer is anxious to do justice to the memory of a man, whose virtues he re. spected, and whose talents be admired; and prove that a generous rivalry, even in the medical profession, is not incompatible with mutual respect and regard.

\section{Crescent Lodge, Clapham Common,} April, 1841.

\section{BRITISH MEDICAL ASSOCIATION.}

$$
\text { Exeter Hall, May 18, } 1841 .
$$

Robert Davidson, Esq., V.P., in the chair.

The minutes of the last meeting were read and confirmed.

W. Self, Esq., 8, Lucas place West, Commercial-road, was unanimously elected a member of the association.

Two cases of application for pecuniary assistance having been reported favourably on by the "Benevolent Purpose Committee," were relieved.

A letter was read from Mr. Warburton, intimating that he had presented the petition of the President and Council of the British Medical Association, in favour of the principles of Mr. Hawes's Medical Bill. A deputation was named to wait on Mr. Hawes, to ascertain, if possible, from the honourable gentleman the course he was likely to pursue with the Medical Bill brought in by him.

After some routine business, the mecting adjourned.

\section{THE \\ APPOINTMENT OF EXAMINERS}

OF THE

\section{UNIVERSITY OF LONDON.}

\section{To the Editor of The LanceT.}

Sir:-It has caused much grief to many in the profession, that discord seems to be raising its head in an institution, towards which we were looking forward with great confidence and expectation, viz., the Univer. sity of London.

It was a general opinion that one of the regulations with which it started, "that the examiners in every department should be changed at certain intervals, so as to bring in the different teachers in succession," would be attended with great and manifest advantages; and that this, with other liberal intentions, would effectually exclude that jobbing monopoly and nepotism which bas gradually crept into most of the medical and surgical institutions in Great Britain and the sister island.

I am sorry, therefore, to observe, that in your pages there is an attack on the council of the London University, for carrying into effect the very principle which would be followed by such good consequences. Now, if blame attaches to them, it should solely be directed to the fact of their re-electing an examiner who had already held that office a year previously.

No journal has more constantly and for. cibly impressed upon the attention of the members of our profession than your own, the fact, " that a public corporate body, like the one in question, should always look to general interests rather than to private ones." Now, the origin of the resignation and complaint lately forwarded to the journals seems to be, that an examiner in the practice of medicine, who last year displaced another, is himself, in the present year, not re-appointed; therefore a newly-appointed examiner in the obstetric department immediately resigns, lest the same fate should await him after a certain period.

It surely would, and with justice, too: The proper view of the transaction is not taken, when it is stated as a sufficient cause for such resignation, "that a faithful and efficient discharge of the duties may be followed by dismissal." For the last word read retirement.

Why, it is an acknowledged principle, that this should be the case; and it is rather too bad, at such an early period, to attempt to compel the university to adopt the opposite rule. The argument pot forward is, that because an examiner conducts himself well in the duties of bis temporary officeergo, displacing him after a certain time, should be looked on as affixing a stigma to his name. This may appear to be very solid 